\title{
Pengaruh Festival Cap Go Meh Terhadap Peningkatan Pendapatan Pada Sektor Perdagangan dan Jasa Kota Singkawang
}

\author{
Singgih Tiwut Atmojo', Nova Wijaya ${ }^{2}$ \\ ${ }^{1}$ STIE Mulia Singkawang \\ Email : singgihatdmodjo3805@gmail.com \\ ${ }^{2}$ STIE Mulia Singkawang \\ Email : novawijaya73@gmail.com
}

\begin{abstract}
Penelitian ini bertujuan untuk melihat pengaruh dari dilaksanakan Festival Cap Go Meh di Kota Singkawang, dan juga untuk melihat seberapa besar pengaruh dari dilaksanakanya Festival Cap Go Meh tersebut khususnya pada sektor perdagangan dan jasa. Dimana diketahui Kota Singkawang yang merupakan salah satu kota tujuan wisata di Kalimantan barat. Pariwisata menjadi andalan di Kota Singkawang khususnya melalui Festival Cap Go Meh ini, sebagaimana diketahui pada perayaan Cap Go Meh sudah menjadi kegiatan budaya rutin yang selalau mampu mendatangkan wisatawan-wisatawan baik luar maupun dalam negeri. Penelitian ini menggunakan metode survey pada pelaku perdagangan dan jasa, sampel dalam penelitian ini berjumlah 100 orang yang terbagi 90 orang pada sektor perdagangan dan 10 pada sektor jasa dengan proporsi 5 pada jasa hotel dan 5 pada jasa taxi (travel). Metode pengumpulan data menggunakan wawancara dan kuisioner. Hasil penelitian menunjukan: (1) Bahwa selama kegiatan festival Cap Go Meh berpengaruh terhadap peningkatan pendapatan di sektor perdagangan dan jasa. (2) Selama kegiatan Festival Cap Go Meh peningkatan pendapatan di sektor perdagangan rata-rata sebesar 42,70\%. (3) Selama kegiatan Festival Cap Go Meh peningkatan pendapatan di sektor jasa rata-rata sebesar 56\%. (4)Pelaku usaha disektor perdagangan merasakan kenaikan pendapatan selama kegiatan festival Cap Go Meh selama 7 hari. (5) Pelaku usaha disektor jasa merasakan kenaikan pendapatan selama kegiatan festival Cap Go Meh selama 6 hari.
\end{abstract}

Kata kunci : Pariwisata, Cap Go Meh, Perdagangan, Jasa

(C) 2019 JBTI. All rights reserved

Article history : Received 27 Jul 2018; Revised 20 Agt 2018; Accepted 20 Sep 2018

\section{PENDAHULUAN}

\section{a. Latar Belakang Masalah}

Steinhoff dalam Madura (2009) menjelaskan bisnis adalah segala kegiatan yang berkaitan dengan penyediaan barang dan jasa yang dibutuhkan dan diinginkan orang. Keluaran bisnis berupa produk meliputi barang (tangible goods) jasa (intangible goods). Steinhoff juga menjelaskan berbagai entitas bisnis yang salah satu diantaranya adalah place dan event. Tempat dapat berupa objek wisata dan event ini dapat berupa kegiatan seperti konser, pertandingan atau kejuaraan olahraga dan bahkan juga festival budaya. Kepariwisataan mempunyai peranan penting untuk memperluas dan memeratakan kesempatan berusaha dan lapangan kerja, mendorong pembangunan daerah, memperbesar pendapatan nasional dalam rangka meningkatkan kesejahteraan dan kemakmuran rakyat serta memupuk rasa cinta tanah air, memperkaya kebudayaan nasional dan memantapkan pembinaannya dalam rangka 
memperkukuh jati diri bangsa dan mempererat persahabatan antar bangsa. Dalam rangka pengembangan dan peningkatan kepariwisataan, diperlukan langkah-langkah pengaturan yang semakin mampu mewujudkan keterpaduan dalam kegiatan penyelenggaraan kepariwisataan, serta mendorong upaya meningkatkan pendapatan disektor dunia usaha.

Sektor pariwisata merupakan sektor yang potensial untuk dikembangkan sebagai salah satu sumber pendapatan daerah. Usaha memperbesar pendapatan asli daerah, maka program pengembangan dan pemanfaatan sumber daya dan potensi pariwisata daerah diharapkan dapat memberikan sumbangan bagi pembangunan ekonomi. Pariwisata dipandang sebagai kegiatan yang mempunyai multidimensi dari rangkaian suatu proses pembangunan. Pembangunan sektor pariwisata menyangkut aspek sosial budaya, ekonomi dan politik (Spillane, 1994). Hal tersebut sejalan dengan yang tercantum dalam Undang-Undang Nomor 10 tahun 2009 Tentang Kepariwisataan yang menyatakan bahwa Penyelenggaraan Kepariwisataan ditujukan untuk meningkatkan pendapatan nasional dalam rangka meningkatkan kesejahteraan dan kemakmuran rakyat, memperluas dan memeratakan kesempatan berusaha dan lapangan kerja, mendorong pembangunan daerah, memperkenalkan dan mendayagunakan obyek dan daya tarik wisata di Indonesia serta memupuk rasa cinta tanah air dan mempererat persahabatan antar bangsa. Perkembangan pariwisata juga mendorong dan mempercepat pertumbuhan ekonomi. Kegiatan pariwisata menciptakan permintaan, baik konsumsi maupun investasi yang pada gilirannya akan menimbulkan kegiatan produksi barang dan jasa. Selama berwisata, wisatawan berbelanja, sehingga secara langsung menimbulkan permintaan pasar barang dan jasa. Selanjutnya wisatawan secara tidak langsung menimbulkan permintaan akan barang modal dan bahan untuk berproduksi memenuhi permintaan wisatawan akan barang dan jasa tersebut. Dalam usaha memenuhi permintaan wisatawan diperlukan investasi di bidang transportasi dan komunikasi, perhotelan dan akomodasi lain, industri kerajinan dan industri produk konsumen, industri jasa, rumah makan restoran dan lain-lain (Spillane, 1994 ).

Singkawang merupakan sebuah daerah yang berada di Kalimantan Barat, Kota ini mempunyai sejuta pesona dan panaroma alam yang menakjubkan bahkan sudah terkenal luas baik secara nasional maupun mancanegara, sehingga banyak orang (wisatawan) yang berkunjung untuk melihat keindahan dan tempat destinasi wisata yang ada di Singkawang. Salah satu yang terkenal yang menjadi destinasi wisata di kota Singkawang adalah festival Cap Go Meh. Berkat Cap Go Meh pula menjadikan Kota Singkawang sangat dikenal sebagai salah satu tujuan wisata khususnya di Kalimantan Barat. Dengan adanya festival Cap Go Meh di Kota Singkawang tentunya akan memberikan manfaat yang besar bagi Masyarakat Kota Singkawang khususnya peningkatan perekonomian masyarakat Kota Singkawang. Sektor-sektor yang menerima manfaat dari kegiatan festival Cap Go Meh khususnya disektor jasa tour guide, sektor transportasi, sektor perhotelan, sektor kuliner dan sektor souvenir.

Hampir semua menantikan perayaan festival Cap Go Meh di Kota Singkawang, Bukan hanya masyarakat dari tionghoa yang terlibat dengan fetival Cap Go Meh namun masyarakat dari suku lain juga menantikan festival Cap Go Meh ini, dengan adanya fetival Cap Go Meh akan banyak wisatawan yang datang di Kota Singkawang baik wisatawan dari luar negeri maupun dalam negeri. Seperti yang disampaikan Sekretaris Dinas Pariwisata, Pemuda, dan Olahraga Singkawang, Suryanto yang menargetkan kunjungan wisatawan datang ke kota singkawang tahun 2018 sebanyak 684.793 orang. Berdasarkan Singkawang dalam Angka tahun 2017 BPS Kota Singkawang melalui sumber data Dinas Perdagangan Perindustrian Koperasi dan UKM Kota Singkawang menunjukan jumlah usaha disektor perdagangan sebagai berikut: 
Tabel 1

Jumlah Perusahaan Perdagangan yang Memiliki Surat Izin Usaha (baru, Her-Reg dan Perubahan) Di Kota Singkawang

\begin{tabular}{|c|l|c|c|c|c|}
\hline No & \multicolumn{1}{|c|}{ Kecamatan } & $\begin{array}{c}\text { Perdagangan } \\
\text { Besar }\end{array}$ & $\begin{array}{c}\text { Perdagangan } \\
\text { Menengah }\end{array}$ & $\begin{array}{c}\text { Perdagangan } \\
\text { Kecil }\end{array}$ & Total \\
\hline 1 & Singkawang Selatan & 10 & 40 & 535 & 582 \\
2 & Singkawang Timur & 5 & 18 & 181 & 204 \\
3 & Singkawang Utara & 4 & 35 & 304 & 343 \\
4 & Singkawang Barat & 13 & 462 & 2278 & 2753 \\
5 & Singkawang Tengah & 12 & 257 & 2015 & 2314 \\
\hline \multicolumn{2}{r|}{2016} & 44 & 842 & 5310 & 6196 \\
& 2015 & 40 & 838 & 4999 & 5879 \\
& 2014 & 41 & 810 & 4632 & 5482 \\
& 2013 & 39 & 780 & 4231 & 5140 \\
& 2012 & 38 & 745 & 3989 & 4772 \\
\hline
\end{tabular}

Sumber : Dinas Perdagangan, Perindustrian, Koperasi dan UKM Kota Singkawang 2017

Jika dilihat dari data tersebut maka jumlah usaha di sektor perdagangan yang paling banyak adalah perdagangan kecil, kemudian perdagangan menengah dan yang terakhir perdagangan besar. Jika dicermati maka jumlah perdagangan kecil selalu berfluktuasi sedangkan di perdagangan menengah dan besar setiap tahunnya jumlahnya selalu meningkat, artinya geliat perdagangan kota singkawang cenderung meningkat hal ini juga dipengaruhi adanya festifal Cap Go Meh.

Sementara itu pada sektor jasa maka data yang akan dilihat adalah jumlah Hotel dan usaha Taxi (Travel) di Kota Singkawang karena kedua jasa tersebut yang menjadi pendukung utama dalam festival Cap Go Meh . Berdasarkan pengamatan dilapangan maka jumlah Hotel di Kota Singkawang dapat dilihat sebagai berikut

Tabel 2

Jumlah Hotel di Kota Singkawang

\begin{tabular}{|l|l|}
\hline No & \multicolumn{1}{|c|}{ Nama Hotel/wisma } \\
\hline 1 & Hotel Swiss Bellin \\
2 & Hotel Dangau \\
3 & Hotel Palapa \\
4 & Hotel Palm Beach \\
5 & Hotel Dayang Resort \\
6 & Hotel Wanaha Inn \\
7 & Hotel Hongkong Inn \\
8 & Hotel Khatulistiwa \\
9 & Hotel Prapatan \\
10 & Hotel Borneo \\
11 & Hotel Kalbar \\
12 & Hotel Simpang \\
13 & Hotel Sinar Khatulistiwa \\
14 & Hotel Tanjung \\
15 & Hotel Sentosa \\
16 & Hotel Restu \\
17 & Hotel Sahabat Baru \\
18 & Hotel Roban Inn \\
19 & Hotel Grand Mandarin \\
\hline
\end{tabular}

Sumber: Data olahan 2018

Sedangkan Perusahaan Taxi berdasarkan pengamatan dilapangan dapat didata jumlah taxi Di Kota Singkawang yang memiliki kantor sendiri sebagai berikut : 
Table 3

Jumlah Perusahaan TAXI (Travel) di Kota Singkawang
\begin{tabular}{|l|l|}
\hline No & \multicolumn{1}{|c|}{ Nama Perusahaan Taxi } \\
\hline 1 & Palapa Taxi \\
2 & Antya Taxi \\
3 & Surya Taxi \\
4 & Dafin Taxi \\
5 & NCS Taxi \\
6 & Kasturi Taxi \\
7 & Tegar Taxi \\
8 & Pachira Taxi \\
9 & Inovasi taxi \\
10 & Ardha Taxi \\
11 & Rahadi Taxi \\
Sumber : Data Olahan 2018 \\
\hline
\end{tabular}

Dengan masuknya wisatawan dalam suatu kota, maka kota memiliki tanggung jawab untuk memenuhi kebutuhan wisatawan yang datang ke kota tersebut, salah satu cara memenuhi kebutuhan wisatawan adalah dengan diciptakannya fasilitas pariwisata seperti hotel, rumah makan, cafe, tour travel, money changer, dan area komersial lainnya. Selain itu juga diharapkan festival Cap Go Meh ini tidak hanya menitik beratkan pada bagaimana menciptakan fasilitas bagi wisatawan tetapi juga mempertimbangkan sejauh mana festival Cap Go Meh ini memberikan dampak bagi perekonomian masyarakat kota singkawang itu sendiri khususnya terhadap tingkat pendapatan pada sektor perdagangan dan jasa. Dengan melihat begitu besarnya potensi festival Cap Go Meh berkaitan dengan peningkatan pendapatan khususnya pada sektor perdaganganan dan jasa. Berdasarka data-data tersebut maka penulis tertarik melakukan penelitian "Pengaruh Festival Cap Go Meh Terhadap Peningkatan Pendapatan Pada Sektor Perdagangan dan Jasa Kota Singkawang”

\section{b. Permasalahan}

Berdasarkan latar belakang tersebut maka permasalahan yang akan di teliti adalah:

1) Apakah terdapat pengaruh kegiatan Festival Cap Go Meh terhadap peningkatan pendapatan disektor perdagangan dan jasa?

2) Seberapa besar pengaruh kegiatan Festival Cap Go Meh terhadap peningkatan pendapatan disektor perdagangan dan jasa?

\section{c. Pembatasan Masalah}

Agar pembahasan tidak menyimpang maka penulis hanya akan menganalisa pengaruh kegiatan festival Cap Go Meh di sektor perdagangan yaitu warung makanan, toko sembako, toko souvenir, warung kelontong dan di sektor jasa yaitu hotel dan taxi (travel).

\section{KAJIAN TEORI}

\section{a. Pariwisata}

Dalam arti luas, pariwisata adalah kegiatan rekreasi diluar domisili untuk melepaskan diri dari pekerjaan rutin atau mencari suasana lain. Sebagai suatu aktifitas, pariwisata telah menjadi bagian penting dari kebutuhan dasar masyarakat maju dan sebagian kecil masyarakat Negara berkembang. Definisi pariwisata menurut Damanik dan Weber (2006) sebagai berikut: Pariwisata adalah fenomena pergerakan manusia, barang, dan jasa yang sangat kompleks. Ia terkait erat dengan organisasi, hubungan-hubungan kelembagaan dan individu, kebutuhan layanan, penyediaan kebutuhan layanan dan sebagainya. Sektor pariwisata merupakan sektor 
yang potensial untuk dikembangkan sebagai salah satu sumber pendapatan daerah. Usaha memperbesar pendapatan asli daerah, maka program pengembangan dan pemanfaatan sumber daya dan potensi pariwisata daerah diharapkan dapat memberikan sumbangan bagi pembangunan ekonomi. Pariwisata dipandang sebagai kegiatan yang mempunyai multidimensi dari rangkaian suatu proses pembangunan. Pembangunan sektor pariwisata menyangkut aspek sosial budaya, ekonomi dan politik (Spillane, 1994).

\section{b. Budaya}

Keanekaragaman budaya Indonesia merupakan peluang peningkatan ekonomi pelaku usaha. Jika pelaku usaha mampu memahami kebudayaan suatu daerah dan menciptakan produk yang sesuai dengan budaya-budaya yang berlaku di suatu daerah. Menurut Suryani Tatik (2008). Mengutip pendapat Hawkins, et al. Budaya diartikan sebagai komplek yang menyeluruh yang mencakup pengetahuan, keyakinan, seni, hukum moral, kebiasaan dan kapabilitas lainnya serta kebiasaan-kebiasaan yang dikuasai oleh indvidu sebagai anggota masyarakat. Dalam kegiataan budaya, tentu akan ada ritual-ritual tertentu yang akan dilakukan yang diyakini dan dipercaya anggota masyarakat. Menurut Mowen (2002) ritual budaya adalah urutan-urutan tindakan yang terstandarisasi yang secara periodik diulang, memberikan arti, dan meliputi penggunaan simbolsimbol budaya. Kota Singkawang sebagai kota pariwisata juga memiliki event budaya yang sangat menarik minat wisatawan datang ke Singkawang. Salah satu event budaya yang sangat terkenal dan mendunia adalah festival budaya Cap Go Meh.

\section{c. Cap Go Meh}

Cap Go Meh melambangkan hari ke-15 dan hari terakhir dari masa perayaan Tahun Baru Imlek bagi komunitas Tionghoa di seluruh dunia. Istilah ini berasal dari dialek Hokkien dan secara harafiah berarti hari kelima belas dari bulan pertama (Cap $=$ Sepuluh, Go $=$ Lima, Meh $=$ Malam). Ini berarti, masa perayaan Tahun Baru Imlek berlangsung selama lima belas hari. Perayaan Cap Go Meh atau hari kelima belas Tahun Baru Imlek di Kota Singkawang, Kalimantan Barat, kurang lengkap tanpa adanya atraksi tatung. Warga etnis Tionghoa di Singkawang meyakini tatung sebagai tokoh yang menjadi medium arwah para ksatria China. Momentum menyambut puncak perayaan Imlek itu pun sepertinya tak mau disia-siakan oleh warga lokal maupun wiatawan yang sudah datang ke Singkawang untuk menyaksikan Festival Cap Go Meh. Ini terbukti dengan datangnya ribuan orang, termasuk turis mancanegara. Festival ini biasanya melibatkan ratusan tatung yang memperlihatkan kesaktian mereka.

\section{d. Perdagangan}

Perdagangan atau perniagaan pada umumnya ialah pekerjaan membeli barang dari suatu tempat atau pada suatu waktu dan menjual barang itu ditempat lain atau pada waktu yang berikut dengan maksud untuk memperoleh keuntungan. Dalam Buku I Bab 1 Pasal 2 sampai dengan Pasal 5 KUHD diatur tentang pedagang dan perbuatan perdagangan. Pedagang adalah orang yang melakukan perbuatan perdagangan sebagai pekerjaan sehari-hari (Pasal 2 KUHD). Pengertian perdagangan atau perniagaan dalam Pasal 3 Kitab Undang-Undang Hukum Dagang (KUHD) adalah membeli barang untuk dijual kembali dalam jumlah banyak atau sedikit, masih berupa bahan atau sudah jadi, atau hanya untuk disewakan pemakaiannya. Berkaitan dengan hal tersebut, untuk menyempurnakan ketentuan diatas maka perbuatan perdagangan juga dirumuskan dalam beberapa peraturan perundang-undangan. Dalam Pasal 1 butir 1 Surat Keputusan Menteri Perindustrian dan Perdagangan (Kepmenperindag) Nomor 23/MPM/Kep/1998 tentang Lembaga-Lembaga Usaha Perdagangan, perdagangan adalah kegiatan jual beli barang dan/atau jasa yang dilakukan secara terus-menerus dengan tujuan pengalihan hak atas barang dan/atau jasa dengan disertai imbalan atau kompensasi. Kegiatan 
perdagangan tentu saja mencakup juga kegiatan jual beli, karena pada dasarnya jual beli merupakan bagian dari perdagangan.

Menurut Burgerlijk Wetboek dalam Mangunsong (2008) jual beli adalah perjanjian timbal balik dimana pihak yang satu berjanji untuk menyerahkan hak milik atas suatu barang, sedang pihak lainnya berjanji untuk membayar harga yang terdiri atas sejumlah uang sebagai imbalan dari perolehan hak milik tersebut, sedangkan menurut Pasal 1457 Kitab UndangUndang Hukum Perdata (KUHPdt) jual beli merupakan suatu persetujuan dimana pihak yang satu mengikatkan dirinya untuk menyerahkan suatu kebendaan dan pihak yang lain membayar harga yang telah djanjikan. Berdasarkan pada rumusan tersebut, dapat kita ketahui bahwa jual beli merupakan suatu bentuk perjanjian yang melahirkan kewajiban atau perikatan untuk memberikan sesuatu, yang dalam hal ini terwujud dalam bentuk penyerahan kebendaan yang dijual oleh penjual dan penyerahan uang oleh pembeli kepada penjual. Maka dari itu dapat disimpulkan bahwa pada dasarnya kegiatan perdagangan dan jual beli merupakan kegiatan ekonomi yang mempunyai keterkaitan antara satu dengan lainnya, karena kegiatan perdagangan yang utama adalah membawa barang-barang dari produsen (penghasil) ketempat-tempat konsumen (pemakai), sedangkan kegiatan jual beli yang terpenting adalah mengecerkan barang secara langsung. Berbeda dengan perdagangan yang hanya terbatas pada kegiatan menjual kembali, jual beli memiliki arti yang lebih luas.

\section{e. Jasa}

Menurut Kotler (2016) Jasa didefinisikan sebagai setiap tindakan atau kinerja yang dapat ditawarkan satu pihak kepada pihak lain, yang pada dasarnya tidak berwujud dan tidak mengakibatkan kepemilikan sesuatu. Karakteristik jasa menurut Setiyaningrum (2015) "ada lima karakteristik khusus jasa, yaitu :

a. Intangible

Jasa bersifat tidak berwujud. Sebuah barang tersusun dari materi berwujud, sedangkan jasa merupakan kinerja yang tidak memiliki wujud yang solid. Jasa tidak dapat dilihat, disentuh dan dicium.

b. Inseparability

Sebagian jasa memiliki sifat tidak terpisahkan antara produksi dan konsumsi jasa. Jasa dikonsumsi saat jasa tersebut diproduksi.

c. Variability

Kualitas jasa lebih bervariasi dibandingkan dengan barang. Personel jasa yang berbeda, outlet jasa yang berbeda, dan waktu pemakaian yang berbeda dapat menyebabkan variasi dalam kualitas

d. Perishability

Jasa bersifat tidak dapat disimpan. Kapasitas jasa yang tersedia bersifat sensitif terhadap perubahan waktu. Dengan berlalunya waktu, kapasitas jasa yang tidak terpakai akan hilang.

e. Difficult to Understand

Jasa cenderung sulit dipahami. Beberapa jasa melalui tahapan-tahapan yang rumit dan tidak mudah dimengerti."

\section{METODE PENELITIAN}

Penelitian ini menggunakan metode survey, menurut Sugiyono (2013) penelitian survey adalah penelitian yang dilakukan dengan menggunakan populasi besar maupun kecil, tetapi data yang dipelajari adalah data dari sampel yang diambil dari populasi tersebut, untuk menemukan kejadian-kejadian ralatif, distribusi dan hubungan-hubungan antar variabel sosiologis maupun psikologis. Metode pengumpulan data dalam penelitian ini menggunakan teknik wawancara dan kuisioner. populasi dari penelitian ini adalah semua pengusaha yang bergerak di sektor 
perdagangan dan sektor jasa, sampel dalam penelitian ini menggunakan 100 sampel yang terdiri dari 90 sampel dari sektor perusahaan perdagangan, 5 sampel dari sektor jasa peruahaan perhotelan dan 5 sampel dari sektor jasa perusahaan transportasi. Teknik pengambilan sampel dalam penelitian ini menggunakan non probability sampling. Hal ini disebabkan tidak diketahuinya probabilitas sampel yang akan dipilih. Dikarenakan populasi dalam penelitian ini jumlahnya tidak terbatas (infinit), maka Jumlah sample penelitian ditetapkan dengan menggunakan sampling kuota. Menurut Sugiyono (2013) samplin kuota adalah teknik untuk mengumpulkan sampel dari populasi yang mempunyai ciri-ciri tertentu sampai jumlah (kuota) yang dinginkan.

\section{HASIL DAN PEMBAHASAN}

Berdasarkan hasil jawaban maupun pendapat responden terhadap sepuluh item pertanyaan yang diajukan didapat hasil sebagai berikut:

a. Tanggapan responden mengenai pendapatan yang diterima dalam kondisi normal pada sektor perdagangan.

Didapatkan hasil bahwa rata-rata pendapatan kotor responden perhari dalam kondisi tidak ada Festival Cap Go Meh terbanyak yaitu Rp.1.000.000 s,d Rp.3.000.000 perhari sebanyak 65 responden atau 73 persen, yang terbanyak kedua pendapatan kotor diterima perhari yaitu Rp.3.100.000 s.d Rp.5.000.000 sebanyak 16 responden atau 18 persen, yang terbanyak ketiga pendapatan kotor diterima perhari yaitu Rp.5.100.000 s.d Rp.7.000.000 sebanyak 7 responden atau 8 persen dan, yang terbanyak keempat pendapatan kotor diterima perhari yaitu Rp.7.000.000 ke atas sebanyak 2 responden atau 2 persen. Secara umum responden yang terbanyak adalah responden yang memiliki pendapatan kotor perhari Rp.1.000.000 s.d Rp.3.000.000.

b. Tanggapan responden mengenai pendapatan yang diterima dalam kondisi normal pada sektor jasa.

Diketahui bahwa rata-rata pendapatan kotor responden perhari dalam kondisi tidak ada event Festival Cap Go Meh yaitu Rp.1.000.000 s,d Rp.3.000.000 perhari sebanyak 1 responden atau 10 persen, kedua pendapatan kotor diterima perhari yaitu Rp.3.100.000 s.d Rp.5.000.000 sebanyak 2 responden atau 20 persen, yang ketiga pendapatan kotor diterima perhari yaitu Rp.5.100.000 s.d Rp.7.000.000 sebanyak 6 responden atau 60 persen dan , yang keempat pendapatan kotor diterima perhari yaitu Rp.7.000.000 ke atas sebanyak 1 responden atau 10 persen. Secara umum responden yang terbanyak adalah responden yang memiliki pendapatan kotor perhari Rp.5.100.000 s.d Rp.7.000.000 Dilihat dari jumlah perhasilan kotor yang diterima responden maka disektor jasa memiliki pendapatan yang terbesar jika dibandingkan sektor pedagangan, hal ini dikarenakan pada penelitian ini disektor jasa adalah usaha-usaha yang cukup besar dan modal yang besar seperti bisnis Hotel/rumah kost dan jenis usaha transportasi dalam hal ini Taxi.

c. Tanggapan responden mengenai apakah Festival Cap Go Meh di kota singkawang berpengaruh pada peningkatan pendapatan di sektor perdagangan

Diketahui bahwa disektor perdagangan terdapat 74 responden atau 82 persen mengatakan bahwa Kegiatan Festival Cap Go Mehh mempunyai pengaruh terhadap peningkatan pendapatan para pengusaha disektor perdagangan, hal ini dikarenakan bahwa tempat usaha para pengusaha disektor perdagangan tidak terlalu jauh dengan kegiatan Festival Cap Go Meh seperti tempat usaha dilewati oleh tatung, tempat usaha dekat dengan vihara yang 
dijadikan tempat ritual tatung, tempat usaha dekat dengan pemeran. Sedangkan 16 responden atau 18 persen mengatakan bahwa Kegiatan Festival Cap Go Meh tidak mempunyai pengaruh terhadap peningkatan pendapatan para pengusaha disektor perdagangan, hal ini dikarenakan tempat usaha jauh dari kegiatan festival Cap Go Meh. Secara umum dapat diasumsikan bahwa kegiatan Festival Cap Go Meh mempunyai dampak positif bagi dunia usaha khususnya disektor Perdagangan.

d. Tanggapan responden mengenai apakah Festival Cap Go Meh di kota singkawang berpengaruh pada peningkatan pendapatan di sektor jasa.

Disektor Jasa dapat diketahui bahwa Festival Cap Go Meh mempunyai pengaruh terhadap peningkatan pendapatan para pengusaha disektor jasa maka 10 responden atau 100 persen mengatakan bahwa Festival Cap Go Meh mempunyai pengaruh terhadap peningkatan pendapatan para pengusaha disektor jasa, hal ini dikarenakan bahwa wisatawan yang berkunjung ke Kota Singkawang menyaksikan Festival Cap Go Meh memerlukan tempat menginap dan kendaraan untuk mobiliasi. Secara umum dapat diasumsikan bahwa kegiatan Festival Cap Go Meh mempunyai dampak positif bagi dunia usaha khususnya disektor Jasa yaitu bisnis perhotelan/kost dan bisnis layanan transportasi.

a. Tanggapan responden mengenai berapa persen peningkatan pendapatan karena kegiatan Festival Cap Go Meh di kota singkawang di sektor perdagangan.

Hasil menunjukan adanya kegiatan Cap Go Meh para pengusaha disektor perdagangan maka 27 responden atau 36,48 persen mengatakan bahwa Kegiatan Festival Cap Go Meh meningkatkan pendapatan pegusaha disektor perdagangan antara $31 \%$ s.d $40 \%, 20$ responden atau 27,02 persen mengatakan bahwa Kegiatan Festival Cap Go Meh meningkatkan pendapatan pegusaha disektor perdagangan antara 51\% s.d 60\%, 13 responden atau 17,56 persen mengatakan bahwa Kegiatan Festival Cap Go Meh meningkatkan pendapatan pegusaha disektor perdagangan antara 41\% s.d 50\%, 7 responden atau 9,45 persen mengatakan bahwa Kegiatan Festival Cap Go Meh meningkatkan pendapatan pegusaha disektor perdagangan antara $21 \%$ s.d $30 \%, 5$ responden atau 6,75 persen mengatakan bahwa Kegiatan Festival Cap Go Meh meningkatkan pendapatan pegusaha disektor perdagangan antara $61 \%$ s.d $70 \%$ dan 2 responden atau 2,70 persen mengatakan bahwa Kegiatan Festival Cap Go Meh meningkatkan pendapatan pegusaha disektor perdagangan antara $10 \%$ s.d $20 \%$. Jika dianalisis data yang ada 60 responden atau $81 \%$ dari total 74 respoden mengatakan bahwa Kegiatan Festival Cap Go Meh meningkatkan pendapatan pegusaha disektor perdagangan rata-rata sebesar 42,70\%

b. Tanggapan responden mengenai berapa persen peningkatan pendapatan karena kegiatan Festival Cap Go Meh di kota singkawang di sektor jasa.

Hasil tanggapan dari 6 responden atau 60 persen mengatakan bahwa Kegiatan Festival Cap Go Meh meningkatkan pendapatan pegusaha disektor jasa diatas 70\%, 4 responden atau 40 persen mengatakan bahwa Festival Cap Go Meh meningkatkan pendapatan pegusaha disektor jasa antara $31 \%$ s.d $40 \%$, Jika dianalisis data yang ada semua respoden yang usahanya bergerak disektor jasa mengatakan Festival Cap Go Meh meningkatkan pendapatan pengusaha disektor jasa. Rata-rata kenaikan pendapatan tersebut sebesar 56\%. Jika dibandingkan antara sektor usaha perdagangan dengan sektor usaha jasa maka yang paling merasakan kenaikan pendapatan atas kegiatan Fetival Cap Go Meh di Kota Singkawang adalah sektor usaha jasa rata-rata sebesar $56 \%$, sedangkan sektor usaha perdagangan hanya rata-rata sebesar $42,70 \%$ 
c. Tanggapan responden mengenai berapa hari merasakan peningkatan pendapatan karena kegiatan Festival Cap Go Meh di kota singkawang di sektor perdagangan.

Pada sektor perdagangan hasil menunjukan 50 responden atau 67,56 persen mengatakan bahwa pengusaha disektor perdagangan merasakan kenaikan pendapatan karena Kegiatan Festival Cap Go Meh selama 7 hari, 9 responden atau 12,16 persen mengatakan bahwa pengusaha disektor perdagangan merasakan kenaikan pendapatan karena Kegiatan Festival Cap Go Meh selama 10 hari, 5 responden atau 6,75 persen mengatakan bahwa pengusaha disektor perdagangan merasakan kenaikan pendapatan karena Kegiatan Festival Cap Go Meh selama 12 hari ke atas, 4 responden atau 5,40 persen mengatakan bahwa pengusaha disektor perdagangan merasakan kenaikan pendapatan karena Kegiatan Festival Cap Go Meh selama 2 hari. Jika dianalisis data dan dirata-ratakan dari total 74 respoden mengatakan bahwa Kegiatan Festival Cap Go Meh merasakan peningkatan pendapatan pegusaha disektor perdagangan rata-rata selama 7 hari.

d. Tanggapan responden mengenai berapa hari merasakan peningkatan pendapatan karena kegiatan Festival Cap Go Meh di kota singkawang di sektor jasa.

Pada sektor jasa maka 3 responden atau 30 persen mengatakan bahwa pengusaha disektor perdagangan merasakan kenaikan pendapatan karena Kegiatan Festival Cap Go Meh selama 7 hari dan 4 hari, 2 responden atau 20 persen mengatakan bahwa pengusaha disektor perdagangan merasakan kenaikan pendapatan karena Kegiatan Festival Cap Go Meh selama 12 hari keatas, Jika dianalisis data dan dirata-ratakan dari total 10 respoden mengatakan bahwa Kegiatan Festival Cap Go Meh merasakan peningkatan pendapatan pegusaha disektor jasa selama 6 hari. Jika dibandingkan antara sektor usaha perdagangan dengan sektor usaha jasa maka yang paling merasakan kenaikan pendapatan atas kegiatan Festival Cap Go Meh di Kota Singkawang adalah sektor usaha perdaganagan selama 7 hari, sedangkan sektor usaha jasa rata-rata selama 6 hari.

e. Tanggapan responden mengenai apakah menambah karyawan selama kegiatan Festival Cap Go Meh di kota singkawang di sektor perdagaangan.

Hasil menunjukan bahwa 69 responden atau 93,25 persen mengatakan bahwa tidak menambah tenaga kerja dengan adanya fetival Cap Go Meh. Ini di karenakan pengusaha di sektor perdagangan masih bisa melayani pelanggan dengan baik walaupun dalam situasi perayaan festival Cap Go Meh. 5 responden atau 6,75 persen mengatakan bahwa menambah tenaga kerja dengan adanya fetival Cap Go Meh. Hal ini dikarenakan jumlah permintaan dari konsumen meningkat sehingga perlu ditambah tenaga kerja untuk melayani konsumsen. Namun penambahan tenaga kerja tidak berlangsung lama karena setelah selesai festival Cap Go Meh tenaga kerja yang direkrut diberhentikan kembali. Secara umum dapat diasumsikan bahwa kegiatan Festival Cap Go Meh tidak berdampak positif dalam jangka pangjang untuk penambahan karyawan di sektor perdagangan.

f. Tanggapan responden mengenai apakah menambah karyawan selama kegiatan Festival Cap Go Meh di kota singkawang di sektor jasa.

Hasil menunjukan bahwa 9 responden atau 90 persen mengatakan bahwa tidak menambah tenaga kerja dengan adanya fetival Cap Go Meh. Ini di karenakan pengusaha di sektor jasa masih bisa melayani pelanggan dengan baik walaupun dalam situasi perayaan festival Cap Go Meh. 1 responden atau 10 persen mengatakan bahwa menambah tenaga kerja dengan adanya fetival Cap Go Meh. Hal ini dikarenakan jumlah permintaan dari konsumen meningkat sehingga perlu ditambah tenaga kerja untuk melayani konsumsen. Namun sama dengan di sektor perdagangan penambahan tenaga kerja tidak berlangsung lama karena 
setelah selesai festival Cap Go Meh tenaga kerja yang direkrut diberhentikan kembali. Secara umum dapat diasumsikan bahwa kegiatan Festival Cap Go Me tidak berdampak positif dalam penambahan tenaga kerja di sektor jasa.

\section{KESIMPULAN}

Berdasarkan penelitian yang telah dilakukan terhadap pengaruh festival Cap Go Meh terhadap peningkatan pendapatan disektor perdagangan dan jasa, maka dapat diambil kesimpulan sebagai berikut:

a. Bahwa selama kegiatan festival Cap Go Meh berpengaruh terhadap peningkatan pendapatan di sektor perdagangan dan jasa. Hal ini sejalan dengan hasil penelitian Ocsuanda (2018) yang menyatakan bahwa Rumah makan adalah fasilitas pariwisata yang paling dominan berkembang dibandingkan fasilitas pariwisata lainnya, kemudian fasilitas pariwisata hotel merupakan fasilitas yang lebih menarik diantara pertumbuhan fasilitas pariwisata lainnya. Menunjukan bahwa secara umum peningkatan pendapatan pada sektor perdagangan di dominasi pada usaha Rumah Makan sementara pada sektor jasa di dominasi pada usaha jasa perhotelan. Yang ditandai dengan hasil bahwa selama kegiatan Festival Cap Go Meh peningkatan pendapatan di sektor perdagangan rata-rata sebesar 42,70\%. Sementara itu pada sektor jasa selama kegiatan Festival Cap Go Meh peningkatan pendapatan di sektor jasa rata-rata sebesar $56 \%$.

b. Pengusaha disektor perdagangan merasakan kenaikan pendapatan selama kegiatan festival Cap Go Meh selama 7 hari. Sementara pengusaha disektor jasa merasakan kenaikan pendapatan selama kegiatan festival Cap Go Meh selama 6 hari. Hal ini dianggap masih belum maksimal karena diharapkan dari festival berskala nasional ini selain tidak hanya mampu meningkatkan persentase pendapatan tetapi juga mampu meningkatkan kesejahteraan seluruh masyarakat kota singkawang tidak hanya masayarakat sekitar yang dilalui festival Cap Go Meh ini saja dan juga peningkatan pendapatan yang diharapkan itu dapat meningkat tidak hanya musiman atau hanya pada periode waktu tertentu saja. Artinya disinalah peran penting Pemerintah Kota Singkawang untuk memberikan perhatian yang lebih terhadap festival Cap Go Meh ini dengan melihat begitu besarnya potensi dari festival ini dan juga dampat positif dari pariwisata dalam pembangunan kota. Saat ini dampak yang dirasakan masih sangat sedikit terbukti dari hasil penelitian yang menunjukan peningkatan pendapatan hanya terjadi pada periode tertentu saja. Hasil ini juga sejalan dengan penelitian Ocsuanda (2018) bahwa perkembangan pariwisata dapat memberikan pengaruh terhadap perkembangan kota secara positif, terutama di Kota Singkawang. Seluruh perubahan ini paling banyak dilakukan oleh masyarakat atau pihak swasta, dan masih memerlukan bantuan Pemerintah Daerah. Begitu juga dengan penelitian Riskiyah (2018) bahwa dukungan pemerintah (sebagai variabel proses) masih diperlukan dalam menyukseskan festival Cap Go Meh, Pemerintah Kota perlu meningkatkan subsidi bagi para pihak yang terlibat dalam festival ini.

\section{SARAN} berikut:

Dari penelitian ini beberapa masukan dari respoden dapat disaran adalah sebagai

a. Kegiatan festival Cap Go Meh perlu di tingkatkan agar lebih meriah lagi.

b. Cakupan wilayah kegiatan festival Cap Go Meh dapat diperluas tidak hanya di daerah pasar saja namun juga dapat dilakukan di daerah pinggiran Kota Singkawang.

c. Pemerintah Kota Singkawang perlu untuk meningkatkan fasilitas umum seperti Taman, Information center dan WC Umum dibeberapa tempat agar para wisatawan lebih merasa nyaman dan mudah mencari informasi. 


\section{DAFTAR PUSTAKA}

Damanik, Janianton dan Weber, Helmut. 2006. Perencanaan Ekowisata Dari Teori Ke Aplikasi. PUSPAR UGM dan Andi. Yogyakarta

Dinas Perdagangan Perindustrian Koperasi dan UKM Kota Singkawang Tahun 2017

John C. Mowen, Michael Minor. 2002. Perilaku Konsumen (Jilid 1) Edisi Kelima. Erlangga. Jakarta.

Kotler, Philip., dan Kevin L. Keller.2016. Marketing Managemen.” $15^{\text {th }}$ Edition. Pearson Education, Inc.

Madura, J. 2009. Introduction To Business Pengantar Bisnis 1, $4^{\text {th }}$ edition, Salemba Empat. Jakarta

Mangunsong, Rany . 2008: Indonesian Civil Code - Burgerlijk Wetboek voor Indonesia (Kitab Undang-Undang Hukum Perdata). Gramedia Pustaka Utama. Jakarta.

Setiyaningrum, Ari.2015. Prinsip-Prinsip Pemasaran. Andi Offset. Yogyakarta.

Riskiyah, Putri. 2018. Pengaruh Bauran Pemasaran Terhadap Keputusan Mengunjungi Festival Cap Go Meh di Singkawang. Jurnal Pariwisata, Vol 5, No 1.

Spillane, J James. 1994. Pariwisata Indonesia Siasat Ekonomi dan Rekayasa Kebudayaan. Kanisius. Yogyakarta.

Sugiyono. 2013 Metode Penelitian Manajemen. Alfabeta. Bandung

Surat Keputusan Menteri Perindustrian dan Perdagangan (Kepmenperindag) Nomor 23/MPM/Kep/1998 tentang Lembaga-Lembaga Usaha Perdagangan.

Tatik, Suryani. 2008. Perilaku Konsumen Implikasi Pada Strategi Pemasaran. Graha Ilmu. Yogyakarta.

Undang Undang Nomor 10 tahun 2009 Tentang Kepariwisataan.

Vero, Ocsuanda. 2018. Pengaruh Pariwisata Terhadap Perkembangan Kota. Jurnal Muara Sains, Teknologi, Kesehatan dan Ilmu Kesehatan. Vol 2, No 1 